\title{
KEBIJAKAN POLITIK KEUANGAN TERHADAP PEMBANGUNAN NEGARA DALAM SISTEM KETATANEGARAAN ISLAM
}

\author{
Muhammad Syahwalan \\ Mahasiswa Pascasarjana Program Studi Hukum Tata Negara \\ Jalan Raden Fatah Kota Bengkulu \\ Email: syahwalan@iainbengkulu.ac.id
}

\begin{abstract}
Islam has practically taught people about the income-politics policies employed by Prophet Muhammad SAW from the previous period. Zakat has been well-known as one of the state income concept. Zakat is globally a part of 5 (five) pillars of Islam, besides shadat, prayer, fasting, and hajj. One form of responsibility is to maintain finance income and expenditure. One of the things that will be an interesting improvement in this article is about the method of income and budget spending in order to carry out state activities to achieve the goal of prosperity for the society. The results of the study are zakat, ghanimah, fai ', jizya, and kharaj / tax. The revenue from the sources of funds obtained is allocated to public interests such as poverty eradication, state defense and security, legal development, development of infrastructure and social facilities, and education.
\end{abstract}

Keywords: Income; Expenditur; tax; policy.

Abstrak: Di dalam Islam, sumber pendapatan negara sebagai bentuk kebijakan politik yang telah banyak dipraktikan terkhusus pada zaman Rasulullah SAW. Salah satu yang masih familiar dikenal adalah konsep pendapatan dalam bentuk zakat. Sebab secara global, zakat merupakan bagian daripada 5 (lima) rukun Islam/five pillars, selain mengucapkan dua kalimat syahadat, salat, puasa, dan menunaikan ibadah haji ke tanah suci. Salah satu bentuk tanggung jawab tersebut ialah dengan mengelola pendapatan dan pengeluaran dengan baik dan terstruktur. Salah satu hal yang akan menjadi pembahan menarik dalam artikel ini ialah mengenai metode pendapatan dan pembelanjaan anggaran dalam rangka melaksanakan kegiatan negara untuk mencapai tujuan mensejahterakan masyarakat banyak. Dari hasil penelitian ditemukan beberapa sumber keuangan dalam sistem ketatanegaraan Islam yaitu zakat, ghanimah, fai', jizyah. dan kharaj/pajak. Hasil pendapatan dari sumber-sumber dana yang didapat tersebut dialokasikan untuk kepentingan publik seperti seperti pemberantasan kemiskinan, pertahanan dan keamanan negara, pembangunan hukum, pembangungan infrastruktur dan fasilitas sosial, dan bidang pendidikan.

Kata Kunci: Pendapatan; Pengeluaran; Pajak; Kebijakan 
AL-IMARAH: Jurnal Pemerintahan dan Politik Islam

Vol. 4, No. 1, 2019

Pendahuluan

Terbentuknya sebuah negara menimbulkan sebuah konsekuensi yang realistis terkait pelaksanaan ketatanegaraan tersebut, negara dalam arti aktif. Seperti yang dikemukakan oleh Aristoteles dalam buku Ilmu Negara karangan Soehino, S.H. ${ }^{1}$ mengatakan bahwa negara itu dimaksudkan untuk kepentingan warga negaranya, supaya mereka dapat hidup baik dan bahagia. Jadi secara tersirat beliau mengatakan bahwa negara merupakan satu kesatuan yang memiliki tujuan untuk mencapai kebaikan yang tertinggi, dimana kesempurnaan manusia sebagai bagian dari negara. Sehingga dapat digaribawahi bahwa negara memilik tanggung jawab penuh dalam menjamin kehidupan warga negara sebagai sebuah komponen pembentuk negara itu sendiri.

Salah satu bentuk tanggung jawab tersebut ialah dengan mengelola pendapatan dan pengeluaran dengan baik dan terstruktur. Seperti halnya di Indonesia, kebijakan ini menjadi otoritas lembaga kementerian keuangan Republik Indonesia. Salah satu hal yang akan menjadi pembahan menarik dalam artikel ini ialah mengenai metode pendapatan dan pembelanjaan anggaran dalam rangka melaksanakan kegiatan negara untuk mencapai tujuan mensejahterakan masyarakat banyak.

${ }^{1}$ Soehino. Ilmu Negara. Edisi Kedua, Cetakan Pertama. (Yogyakarta: Liberty. 1986. ) h. 24 13
Di dalam Al-quran secara jelas memang tidak diatur mengenai kewajiban untuk membentuk sebuah persekutuan/colony dalam bentuk sebuah negara. Di dalam Alquran tertulis sebagai berikut:

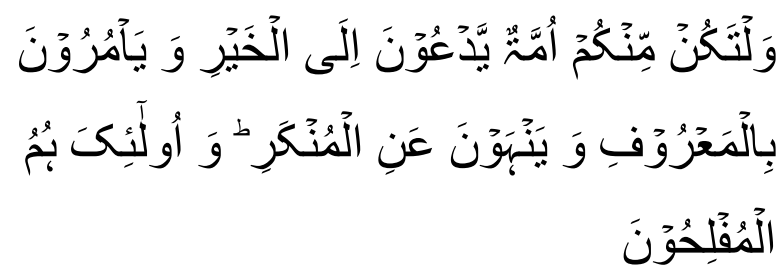

Artinya: dan hendaklah ada di antara kamu segolongan umat yang menyeru kepada kebaikan, menyuruh kepada yang ma'ruf, dan mencegah kepada yang mungkar, merekalah orang-orang yang beruntung. (QS. Al Imran: 104)

Menurut Drs. H. Inu Kencana Syafiie, ayat di atas menerangkan sebuah penjelasan yang menunjukan bahwa segolongan umat tersebut adalah pemerintahan yang sah. Pemerintahan dalam hal ini ialah alat kekuasaan negara dalam menjalankan tugas dan fungsinya sebagai pengatur dan penyelenggara negara. ${ }^{2}$

Di dalam Islam, sumber pendapatan negara telah banyak dipraktikan terkhusus pada zaman Rasulullah SAW. Salah satu yang masih familiar dikenal adalah konsep pendapatan dalam bentuk zakat. Sebab secara global, zakat merupakan bagian daripada 5 (lima) rukun Islam/five pillars, selain mengucapkan dua kalimat syahadat, salat,

\footnotetext{
${ }^{2}$ Inu Kencana Syafiie. Al Qur'an dan Ilmu
} Politik. (Jakarta: Rineka Cipta. 1996.) h. 133 
puasa, dan menunaikan ibadah haji ke tanah suci.

Namun artikel ini tidak hanya akan membahas terkait zakat namun mengupas secara lebih komprehensif sumber-sumber pendapatan lain dalam sistem ketatanegaraan Islam. Serta pembelanjaan yang tepat menurut konsep Islam terkait pendapatan yang diperoleh dari berbagai sumber tersebut demi mencapai tujuan negara untuk memberikan kehidupan yang layak, baik, dan bahagia sebagaimana yang telah dikemukakan oleh Aristoteles di atas.

\section{Pembahasan}

\section{Sumber Pendapatan/Keuangan Negara}

T.M. Hasbi ash-Shiddieqy mengutip pendapat yang dikemukan oleh Abu Yusuf terkait sumber keuangan negara dalam pemerintahan Islam meliputi mawarid aldawlah yang telah ditetapkan oleh syara', yaitu khumus al-ghana'im, sedekah, dan kharaj. Beberapa istilah yang digunakan oleh Abu Yusuf tentang sumber keuangan negara yang sebagain besar tetap terpakai dalam tatanan perundangan negara Islam hingga saat ini adalah zakat, ghanimah, fai', jizyah. dan kharaj/pajak. $^{3}$

\section{a. Zakat}

Dalam Al Qur'an Allah SWT berfirman:

Muhammad Iqbal. Fiqh Siyasah: Kontekstualisasi Doktrin Politik Islam Edisi Pertama. (Jakarta: Prenadamedia Group. 2014. ) h. 317.
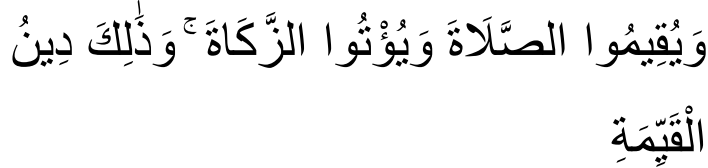

Artinya: ..dan juga agar melaksanakan salat dan menunaikan zakat dan yang demikian adalah agama yang lurus. (QS. Al Bayyinah: 5).

Mengadobsi istilah yang digunakan oleh Hans Kelsen dalam Stufenbau Theory yaitu grundnorm atau norma dasar dalam sebuah sistem peraturan, maka kedudukan AlQur'an sebagai grundnorm dalam sumber hukum Islam tentunya menjadi rujukan awal dalam menentukan sebuah aturan. Termasuk hal ini adalah terkait permasalahan pemungutan zakat seperti yang diatur secara jelas di dalam al-qur'an salah satunya dalam surat tersebut di atas.

Selain itu di dalam hadis, sebagia sumber kedua secara hirarki sumber hukum Islam, juga menjelaskan terkait kewajiban dalam membayar zakat yang terdapat dalam hadis riwayat Bukhari (1308) dan Muslim sebagai berikut:
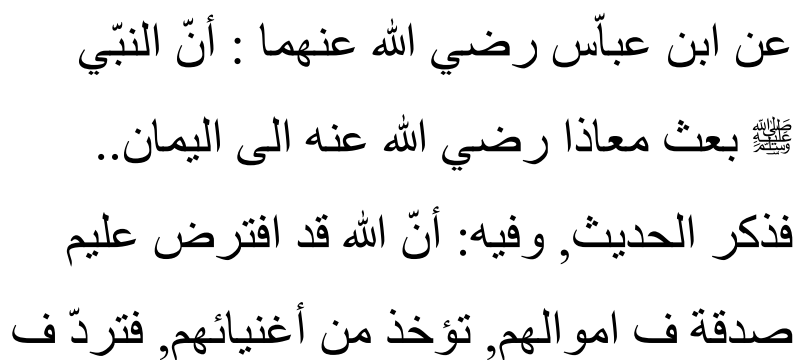
فقر ائهم .متفق عليه, و اللفظ للبخارى.

Artinya: "Dari Ibnu Abbas ra. Bahwasanya Nabi Saw mengutus Muadz ke 
Yaman, lalu menuturkan is hadisnya, dan di dalamnya disebutkan, "Sesungguhnya Allah telah mewajibkan zakat kepada mereka pada harta mereka yang diambil dari orang kaya mereka dan diberikan kepada orang-orang miskin mereka." (HR. BukhariMuslim, dan lafal milik Bukhari)

Zakat berarti bertambah (al-ziyadah), tumbuh dan berkembang, bersih, dan suci. Menurut istilah zakat adalah sejumlah harta tertentu yang diwajibkan Allah SWT untuk diberikan kepada orang-orang yang berhak menerimanya. ${ }^{4}$ Zakat merupakan alat atau istrumen yang digunakan sebagai sumber pendapatan negara dan pendistribusian bagi masyarakat guna menciptakan kehidupan yang sejahtera. Zakat diwajibkan atas harta-harta yang bisa menjadi investasi yang artinya bahwa harta tersebut bisa berkembang dan atau diproduksi serta untuk membersihkan pemiliknya dan membantu orang-orang yang secara nash memiliki hak untuk menerimanya. Zakat terbagi dalam dua macam yaitu: ${ }^{5}$

\section{- Zakat Fitrah}

Fitrah berarti suci, bersih. Sehingga zakat fitrah ialah zakat yang dikeluarkan untuk mensucikan diri sebagai pelengkap kesempurnaan ibadah puasa ramadan yang dilakukan oleh setiap muslim. Dikeluarkannya zakat ini hanya berlaku pada bulan ramadan

${ }_{5}^{4}$ Muhammad Iqbal. ..... h. 318

5 M Nuruddin."Transformasi Hadis-Hadis Zakat dalam Mewujudkan Ketangguhan Ekonomi pada Era Modern. Jurnal Zakat dan Wakaf Vol. 1, No. 2, Desember 2014. h. 305 dan tidak dikeluarkan pada bulan-bulan lain selain itu. Pembayaran zakat fitrah ini berakhir hingga khatib shalat Ied Fitri menaiki mimbar untuk melakukan khutbah. Jumlah zakat yang harus dikeluarkan oleh setiap muslim, menurut Imam Mazhab Syafi'i, yaitu senilai 1 shok atau $2.5 \mathrm{Kg}$ ) untuk setiap pribadi dalam bentuk makanan pokok masing-masing muslim tersebut.

\section{- Zakat Mal}

Zakat Mal Zakat mal atau zakat harta yang wajib di keluarkan zakatnya adalah :

- Emas, perak dan mata uang.

- Hewan ternak, jenis hewan ternak yang wajib di keluarkan zakatnya yaitu unta, sapi, kerbau dan kambing.

- Biji-bijian atau makanan pokok, seperti beras, jagung dan gandum.

- Buah-buahan meliputi kurma dan anggur.

- Harta perniagaan.

- Barang tambang dan harta rikaz (harta terpendam).

Sejumlah sahabat seperti 'Ali ibn Abi Thalib dan generasi tabi'in seperti al-Sya'bi dan Mujahid, sebelumnya juga berpendapat tentang kewajiban selain zakat yang harus dipenuhi oleh orang kaya. Pendapat ini juga dikuarkan dengan pemikiran kontemporer, Sayyid Quthb. Menurutnya zakat adalah batas minimal yang harus dikeluarkan terhadap harta benda, selama masyarakat tidak membutuhkan pendapatan lain selain zakat. Namun bila zakat tidak mencukupi kebutuhan, maka pemerintah berhak melakukan pemungutan lain atas 
pertimbangan pemenuhan kebutuhan penerima zakat (mustahik) menjadi delapan masyarakat. Wewenang ini berpegang kepada jenis: ${ }^{7}$

prinsip al-marshlahah al-mursalah dan sadd al-zari'ah yang meliputi semua usaha untuk menunjang kepentingan masyarakat dan menghilangkan segala bentuk kemudharatan. ${ }^{6}$

Dalam Al Qur'an Allah SWT memberikan pemaparan komprehensif terkait para pihak yang berhak menerima zakat itu sendiri, yaitu:

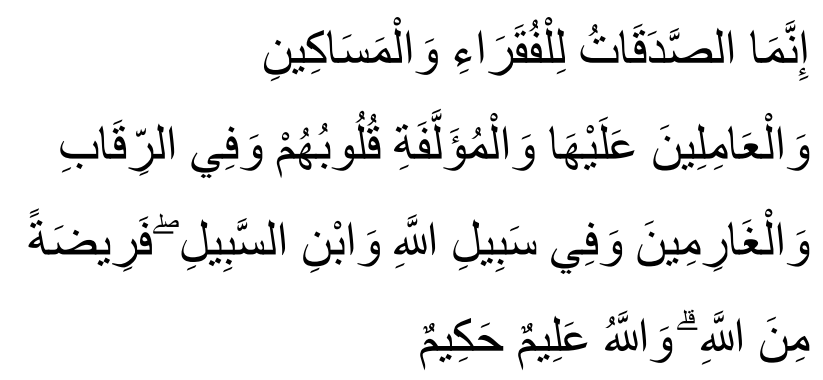

Artinya: Sesungguhnya zakat-zakat itu, hanyalah untuk orang-orang fakir, orangorang miskin, pengurus-pengurus zakat, para mu'allaf yang dibujuk hatinya, untuk (memerdekakan) budak, orang-orang yang berhutang, untuk jalan Allah dan untuk mereka yuang sedang dalam perjalanan, sebagai suatu ketetapan yang diwajibkan Allah, dan Allah Maha Mengetahui lagi Maha Bijaksana. (Q.S At-Taubah: 60).

Dalam bukunya Al-Ahkam AsSulthaniyyah Imam Al-Mawardi membagi

${ }^{6}$ Sayyid Quthb. Al-Adalah al-ijtima'iyah fi alislam (Kairo: Dar al-Kitab al-'Araby, 1980). h. 32 sebagaimana yang terdapat dalam Muhammad Iqbal. Fiqh Siyasah: Kontekstualisasi Doktrin Politik Islam Edisi Pertama. (Jakarta: Prenadamedia Group. 2014. ) h. 320 . a. Jatah pertama diberikan kepada orang fakir yang tidak memiliki apa-apa.

b. Jatah kedua diberikan kepada orang miskin yaitu orang yang mempunyai harta namun tidak memiliki kecukupan. Abu Hanifah berkata bahwa orang miskin lebih menderita daripada fakir. Jatah orang fakir dan jatah orang miskin diberikan kepada keduanya atas nama fakir dan miskin, hingga keduanya berada pada status kaya terendah.

c. Jatah ketiga diberikan kepada para petugas zakat (amil zakat) yang terbagi kedalam dua kelompok yaitu petugas zakat yang bertugas mengambil zakat dan petugas yang bertugas mendistribusikan zakat kepada masyarakat.

d. Jatah keempat diberikan kepada orangorang yang hatinya takluk (mu'allaf). Mereka ada empat kelompok:

- Kelompok yang takluk karena bantuan kaum Muslimin

- Kelompok yang takluk dengan arti berhenti dari mengganggu kaum Muslim

- Kelompok yang takluk karena tertarik kepada Islam

- Kelompok yang takluk karena anjuran kaumnya dan keluarganya untuk masuk Islam.

7 Imam Al Mawardi. Al-Ahkam AsSulthaniyyah: Hukum-hukum Penyelenggaraan Negara dalam. Syariat Islam. (Bekasi: Darul Falah. 2017). h. 218 
e. Jatah kelima diberikan kepada budak. Menurut Imam Syafi'i dan Abu Hanifah, jatah budak diberikan kepada budak mukatib (budak dalam masa pembebasan dengan membayar sejumlah uang kepada tuannya). Mereka diberi sejumlah uang untuk membebaskan dirinya dari tuanya. Imam Malik berkata, “ zakat untuk jatah budak digunakan untuk membebaskan budak".

f. Jatah keenam diberikan kepada orangorang yang berhutang. Mereka terbagi menjadi dua kelompok:

- Orang-orang yang berhutang untuk kepentingan dirinya sendiri. Jika mereka fakir, mereka diberikan uang zakat untuk melunasi hutang mereka.

- Orang yang berhutang untuk kepentingan kaum Muslimin. Mereka diberikan uang zakat sesuai dengan jumlah hutang mereka.

g. Jatah ketujuh diberikan kepada fissabilillah. Mereka adalah orang-orang yang berjuang di jalan Allah SWT.

h. Jatah ke delapan diberikan kepada ibnu sabil, yaitu para musafir yang kehabisan bekal dalam perjalanannya. Mereka diberi zakat sesuai dengan yang mereka butuhkan dalam perjalanan mereka -jika perjalanan mereka tidak untuk maksiatmusafir yang hendak memulai perjalanannya atau sudah memulainya.

\section{b. Ghanimah}

Harta ghanimah adalah harta yang diperoleh umat Islam melalui jalan peperangan. Islam membolehkan umatnya merampas harta musuh yang kalah dalam peperangan. Di dalam Al-Qur'an Allah SWT telah menjelaskan tentang pembagian harta ghanimah:
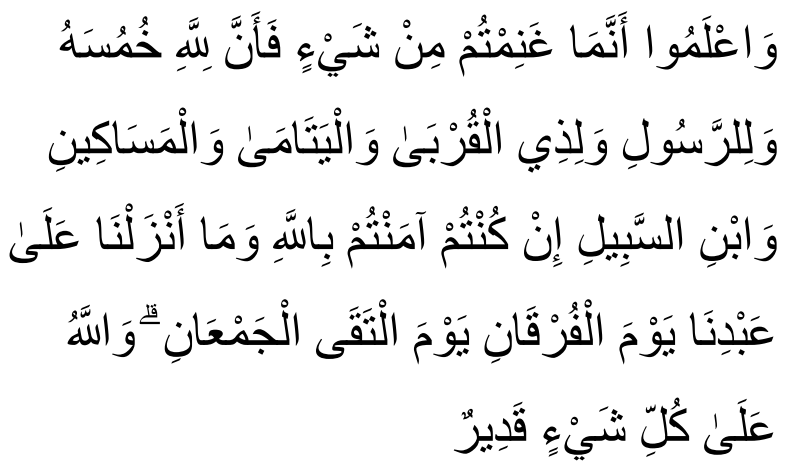

Artinya: Ketahuilah, sesungguhnya apa saja yang dapat kamu peroleh sebagai rampasan perang, maka sesungguhnya seperlima untuk Allah, Rasul, kerabat Rasul, anak-anak yatim, orang-orang miskin dan ibnussabil, jika kamu beriman kepada Allah dan kepada apa yang kami turunkan kepada hamba Kami (Muhammad) di hari Furqaan, yaitu di hari bertemunya dua pasukan. Dan Allah Maha Kuasa atas segala sesuatu. (Q.S. Al Anfal:41)

Menurut al-Mawardi, ghanimah meliputi usara (tentara musuh yang berhasil ditawan), sabiy (tawanan yang bukan berasal dari tentara, seperti anak-anak, wanita, dan orang tua jompo), harta benda yang bergerak, tanah serta harta lainnya yang tidak bergerak.

Berdasarkan dalil naqli yang termaktub dalam Q.S Al Anfal ayat (41), Allah SWT mengambilalih mekanisme porsi pembagian 
harta ghanimah. Jumlah 1/5 dari harta tersebut diperuntukan untuk Allah SWT, Rasul SAW, karib kerabat, anak yatim, dan fakir miskin. Pembagian ini kemudian dilakukan oleh nabi pada perang Badar. Adapun sisanya yang empat perlima, meskipun secara eksplisit tidak dijelaskan oleh Allah SWT, dipahami oleh para ulama sebagai bagian dari yang harus dibagi-bagikan untuk tentara yang ikut berperang. Cara pembagiannya, sebagaimana yang dilakukan Nabi SAW, adalah bagian tentara berkuda adalah lebih besar daripada yang berjalan kaki. Dalam praktiknya, Nabi pernah membagi untuk tentara berkuda dua kali bagian pasukan berjalan kaki, dan di kesempatan lain pernah membaginya menjadi tiga kali lipat. Untuk menentukan cara yang paling baik, maka komandan bisa melihat pertimbangan keadaan dan kondisi serta kemaslahatan. $^{8}$

Sedangkan pembagian mengenai jenis dari ghanimah itu sendiri ialah mencakup tawanan perang, sandera, lahan tanah, dan harta. $^{9}$

\section{- Tawanan Perang}

Ialah orang laki-laki yang terlibat perang, kemudian kaum muslimin berhasil menangkap mereka hidup-hidup. Imam Syafi'i berpendapat bahwa Imam (khalifah) atau wakilnya bebas memilih mana di antara empat opsi yang paling mendatangkan kemaslahatan jika mereka tetap bertahan dalam kekafirannya;

\footnotetext{
${ }^{8}$ Muhammad Iqbal. ..... h. 322.

${ }^{9}$ Imam Al Mawardi. ...h. 233
}

membunuh mereka, menjadikan mereka sebagai budak, mereka ditebus dengan uang atau pertukaran tawanan, dan membebaskan mereka tanpa uang tebusan.

\section{- Sandera}

Yang dimaksud dengan sandera ialah wanita dan anak-anak. Jika mereka berasal dari ahli kitab, mereka tidak boleh dibunuh, karena Rasulullah SAW melarang pembunuhan terhadap wanita dan anak-anak. Mereka akan menjadi budak dan dibagi-bagikan bersama dengan rampasan perang lainnya. Jika sandera wanita menebus dirinya dengan uang, maka diperbolehkan dengan alasan bahwa penebusan ini termasuk dalam kategori jual beli, dan uang tebusan itu menjadi ghanimah. Jika imam ingin mengadakan pertukaran tawanan dengan tawanan perang kaum Muslim yang ada pada ornag-orang kafir, maka sebagai gantinya orang-orang yang menangkap tawanan perang tersebut diberi ganti rugi dari jatah kepentingan umum.

\section{- Lahan Tanah}

Jika kaum Muslimin berhasil menguasai lahan tanah, maka lahan tanah tersebut terbagi kedalam tiga bagiang:

Pertama, lahan tanah yang dikuasai kaum Muslimin dengan kekerasan, dan secara paksa, hingga orang-orang kafir meninggalkanny; baik dengan pembunuhan, atau penyanderaan, atau pengusiran. Imam Syafi'i berpendapat 
bahwa lahan tanah yang diperoleh tersebut termasuk dalam kategori ghanimah yang didistribusikan kepada orang-orang yang mendapatkannya, kecuali kalau mereka dengan kerelaan hati melepaskan haknya atas lahan-lahan tanah tersebut, kemudian lahan tersebut diwakafkan untuk kepentingan umum kaum Muslimin.

Kedua, lahan tanah yang dikuasai oleh kaum Muslimin dengan damai, karena orang-orang kafir meninggalkannya karena ketakutan. Dengan penguasaan ini maka tanah tersebut menjadi tanah wakaf. Ketiga, kaum muslimin menguasai lahan tanah tersebut secara damai dengan ketentuan lahan tanah tersebut tetap mereka miliki, namun mereka membayar pajaknya.

\section{- Harta benda bergerak}

Harta benda bergerak termasuk ghanimah yang bisa ditolerir. Dalam sebuah riwayat disebutkan bahwa Ubadah bin Shamit menjelaskan bahwa firman Allah SWT dalam surat An Anfal ayat (1) turun sebagai akibat dari perebutan harta hasil dari perang badar. Kemudian pada ayat (41) Allah SWT secara rinci menjelaskan tentang pembagian ghanimah dan menginstruksikan Nabi SAW membaginya secara langsung. Beliau membagi ghanimah secara rata kepada kaum Muslimin.

\section{c. Fai}

Fai' ialah harta yang diperoleh dari musuh tanpa peperangan. Pada prinsipnya fai' dibagikan untuk pasukan Islam, setelah terlebih dahulu dikeluarkan hak Allah SWT, Rasulullah SAW, karib kerabat Rasul SAW, anak yatim, fakir miskin, dann ibn sabil. ${ }^{10} \mathrm{Al}$ Mawardi mengatakan bahwa sesungguhnya semua harta yang didapatkan oleh kaum Muslimin dari orang-orang musyrik dengan sukarela tanpa melalui pertempuran, tanpa derap kaki kuda dan pengendaranya, maka ia seperti uang perdamaian. Jika imam ingin menjalin hubungan dengan salah satu kelompok untuk menciptakan kemaslahatan umum kaum Muslimin seperti menjalin hubungan dengan para duta besar negara lain dan muallaf, ia boleh mengambil fai' untuk kepentingan tersebut karena Rasulullah SAW pernah memberikan pernah memberikan sejumlah harta kepada para muallaf pada perang Hunain.

\section{d. Jizyah}

Jizyah ialah pajak kepala yang dibayarkan oleh penduduk dar al Islam yang bukan Muslim kepada pemerintah Islam. Kata jizyah diambil dari kata jaza' yang berarti imbalan, yaitu imbalan sebagai bentuk prestasi atas kesetiaan non Muslim maka diberikan perlindungan dan rasa aman. Landasan normatif dari pemungutan jizyah ini terdapat dalam firman Allah SWT berikut: 


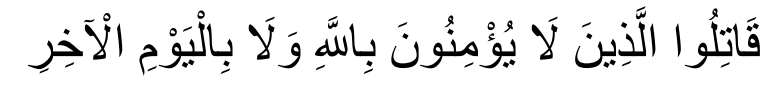

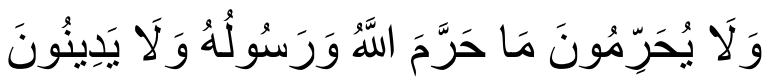
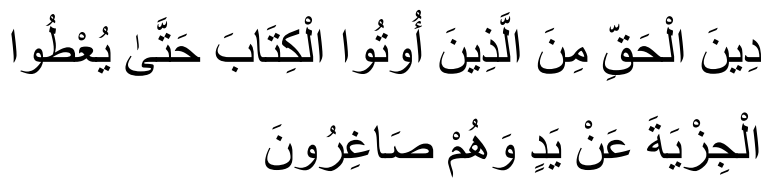

Artinya: Perangilah orang-orang yang

tidak beriman kepada Allah dan tidak (pula) kepada hari kemudian, dan mereka tidak mengharamkan apa yang diharamkan oleh Allah dan Rasul-Nya dan tidak beragama dengan agama yang benar (agama Allah), (yaitu orang-orang) yang diberikan Al-Kitab kepada mereka, sampai mereka membayar jizyah dengan patuh sedang mereka dalam keadaan tunduk. (Q.S. At-Taubah: 29)

Pihak yang berwenang harus mengenakan jizyah kepada setiap orang dari ahli kitab yang masuk dalam jaminan keamanan kaum Muslimin, agar keberadaan mereka diakui di negara Islam. Jika mereka membayar jizyah maka mereka bisa memperoleh hak:

- Mereka tidak boleh diseran

- Mereka dilindungi.

Para Fuqaha berbeda pendapat dalam menentukan jumlah jizyah yang harus dikenakan kepada wajib jizyah. Abu Hanifah membagi orang-orang yang terkena wajib jizyah ke dalam tiga kelompok:

- Orang-orang kaya. Jizyah yang harus dipungut dari mereka adalah sebesar empat puluh dirham.
- Orang-orang menengah. Jizyah yang harus dipungut dari mereka adalah dua puluh empat dirham

- Orang-orang kafir. Jizyah yang harus dipungut ialah sebesar dua belas dirham.

\section{e. Kharaj}

Kharaj dapat diartikan juga sebagai pajak yang dikenakan terhadap tanah dan termasuk hak-hak yang harus ditunaikan. Kharaj pertama kali dikenal dalam Islam setelah perang Khaibar. Pada saat itu Rasulullah SAW memberikan dispensasi kepada para penduduk Yahudi Khaibar untuk memiliki tanah mereka, dengan syarat mereka membayar sebagian hasil panennya kepada pemerintahan Islam. Dalam sejarah pemerintahan Islam, kharaj merupakan sumber keuangan yang dikuasai oleh komunis (pemerintah), bukan oleh kelompok orang. ${ }^{11}$

Muhammad Ashraf membagi jenis kharaj ke dalam dua bentuk yakni, kharaj yang sebanding/proportional dan kharaj yang tetap. $^{12}$ Jenis pertama dikenakan secara proporsional berdasarkan total hasil pertanian misalnya seperdua, sepertiga, atau seperlima dari hasil yan diperoleh. Adapun yang kedua ialah berdasarkan pembebanan atas tanah tanpa membedakan status pemiliknya, baik anak-anak atau dewasa, merdeka atau budak, perempuan, atau laki-laki, Muslim atau non-

11 A.A. Ishlahi. Konsepsi Ekonomi Ibn Taimiyah. (Surabaya: Bina Ilmu Offset, 1997). h. 252253.

${ }^{12}$ Muhammad Ashraf. Economic System Under Umar The Great, terjemahan Irfan Mahmud Ra'na, Sistem Ekonomi Pemerintahan Umar Ubn Al-Khathab. (Jakarta: Pustaka Firdaus, 1992). h. 119 
Muslim. Kewajiban bagi wajib pajak dalam mengeluarkan pajak ialah hanya satu kali dalam satu tahun terlepas dari jumlah hasil panen yang didapatkan.

Penentuan besarnya kharaj yang harus dikeluarkan harus memperhatikan kandungan tanah. Ketika Umar bin Khathab menentukan pajak untuk daerah-daerah Sawad di Irak, maka di salah satu daerah, Umar bin Khathab menetapkan pajak untuk setiap satu jarib (satu jarib=576 hasta) besar pajaknya ialah satu qafiz (satu qafiz= $16 \mathrm{~kg}$ ) dan satu dirham. Jumlah tersebut merupakan hasil ijtihad Kisra bin Qabadz. Dia merupakan orang yang pertama kali mengukur luas tanah, menetapkan pajak, membuat batas dan membuat dokumen.

Namun perlu diperhatikan secara seksama bahwa kharaj dan jizyah secara singkat terlihat sama satu sama lain namun pada prinsipnya kedua sumber pendapatan negara ini ialah berbeda. Adapun letak perbedaan antara kharaj dan jizyah adalah sebagai berikut: ${ }^{13}$

- Jizyah adalah berdasarkan nash (dalil), sedangkan pajak berdasarkan ijtihad.

- Jumlah minimal jizyah ditentukan Syariat, dan jumlah maksimalnya ditentukan oleh ijtihad. Sedangkan kharaj, jumlah minimal dan maksimalnya ditentukan oleh ijtihad.

- Jizyah diambil dari orang kafir jika ia tetap bertahan dalam kekafirannya dan gugur jika dia memutuskan untuk menjadi muallaf, sedangkan kharaj ialah kewajibannya tetap harus dikeluarkan meskipun statusnya adalah seorang Muslim atau kafir.

\section{Pengeluaran dan Belanja Negara}

Negara merupakan bentuk organisasi tertinggi dalam kehidupan manusia. Dengan memiliki persamaan kehendak inilah membentuk sebuah kesepakatan guna menetapkan pengatur (government) dan yang diatur (society). Prof. Bintoro menyebutkan bahwa pemerintah harus memberikan kebebasan kepada masyarakat untuk menumbuhkan perkembangan di berbagai sektor yang berpaham pada filsafat hidup dan filsafat hidup masyarakat tersebut. $^{14}$ Tugas pemerintah adalah antara lain tata usaha negara, rumah tangga negara, pemerintahan, pembangungan dan pelestarian lingkungan hidup, dan memiliki fungsi sebagai pengatur dan pembinaan masyarakat. $^{15}$

Tidak terlepas daripada peran pemerintah sebagai eksekutor dalam pembelanjaan terhadap pendapatan yang diperoleh dari berbagai sumber tersebut di atas. Semua sumber pendapatan keuangan negara dihimpun oleh sebuah lembaga yang memiliki otoritas penuh dalam pengelolaan anggaran negara yang

14 Bintoro Tjokroaminodjojo. Pengantar Administrasi Pembangunan. (Jakarta: LP3ES, 1985). h. 17

15 Prajudi Atmosudirdjo. Hukum Administrasi Negara. (Jakarta: Ghalia Indonesia, 1983). h.11 
Muhammad Syahwalan: Kebijakan Politik Keuangan Terhadap Pembangunan Negara dalam Sistem Ketatanegaraan Islam

disebut Baitul Mal. Menurut Ibn Taimiyah, dana yang dihimpun di Baitul Mal harus dipegang oleh orang yang memiliki otoritas dan integritas agar bisa digunakan untuk kepentingan umum. Dalam hal ini pendistribusian uang negara harus mampu memenuhi rasa keadilan seperti yang diperintahkan oleh Allah SWT dan Nabi SAW. Pada prinsipnya pengelolaan tersebut harus ditujukan untuk mewujudkan kesejahteraan masyarakat dan negara. Di antara pos-pos pengeluaran dan belanja negara yang penting adalah: ${ }^{16}$

\section{- Pemberantasan Kemiskinan}

Tanggung jawab pemerintah diberikan secara paripurna guna melakukan penataan terhadap ekonomi negara agar bisa memenuhi kebutuhan dasar hidup masyarakat. Konsep kapitalisme merupakan bentuk pengelolaan ekonomi yang dilarang dalam agama karena tidak memberikan pemerataan kepada masyarakat umum.

Negara harus mampu memenuhi kebutuhan asasi masyarakat yang meliputi kebutuhan sandang, pangan, dan papan. ${ }^{17}$ Dalam hal ini belanja negara dimaksudkan untuk menciptakan suasana dan iklim yang baik dalam penataan dan

\footnotetext{
${ }^{16}$ Muhammad Iqbal. ..... h. 340

${ }^{17}$ Umer Chapra. Negara Sejahtera Islami dan Perannya di Bidang Ekonomi. Dalam Ainur R. Sophiaan (Ed), Etika Ekonomi Politik Elemen-Elemen Strategis Pembangunan Masyarakat Islam. (Surabaya: Risalah Gusti,1997). h. 152
}

pendistribusian kebutuhan tersebut kepada masyarakat.

\section{Pertahanan dan Keamanan Negara}

Pemerintah wajib memperhatikan pengalokasian keuangan negara kepada hal-hal yang bersifat proteksi terhadap keamaan dan pertahanan wilayah sebuah negara. Salah satu ciri negara yang kuat ialah kuatnya sektor militer dan tingginya tingkat komitmen mereka dalam melakukan pertahanan wilayah dan menajaga keamanan negara. Pengeluaran belanja negara dalam sektor ini bisa berupa penggajian anggota militer, peningkatan kapasitas anggota militer, dan melengkapi alat-alat serta biaya operasional lainnya seperti perlengkapan perang dan pembiayaan terhadap pelatihan perang. Bahkan Imam Al Mawardi mengatakan bahwa tentara resmi dan tentara sukarelawan yang ikut dalam medan peperangan harus diberikan ghanimah dengan jumlah yang sama. Ini merupakan bentuk ajaran yang komprehensi terhadap perhatian negara pada bidang pertahanan dan keamanan.

\section{- Pembangunan Hukum}

Penegakan supremasi hukum merupakanhal yang krusial dalam penataan kehidupan dan ketertiban suatu negara. Dapat dipastikan bahwa jika aturan hukum tidak ditegakkan, maka akan muncul kedaan buruk (chaos) terhadap semua sendi kehidupan dalam 
masyarakat. Penegakkan hukum bukan hanya untuk mencapai ketentraman jiwa setiap individu dalam kelompok masyarakat namun juga demi menciptakan kestabilan ekonomi dan kesejahteraan masyarakat.

Pengeluaran belanja negara dalam bidang penegakkan hukum antara lain untuk meningkatkan kualitas hakim/qadhi, peningkatan kesejahteraan kehidupan hakim guna menciptakan produk-produk hukun yang antisipatif dan responsif terhadap perkembangan dan tantangan yang dihadapi. Hukum bukanlah sekadar kekuasaan semata melainkan menjadi alat dalam melakukan pengaturan masyarakat.

\section{Pembangunan Infrastruktur dan Fasilitas Sosial}

Hal ini dianggap penting guna mendukung pertumbuhan dan perkembangan ekonomi masyarakat yang sehat dan makmur. Pemerintah harus mampu mengarahkan investasi bidang modal fisik pada pembangunan ekonomi untuk kepentingan sosial yang lebih besar.

Salah satu faktor utama pendukung pertumbuhan ekonomi adalah dengan peningkatan dan perbaikan infrastruktur jalan seperti jalan umum, jalan layang, pembangunan irigasi, jembatan, bandar udara, pelabuhan kapal laut, perbaikan layanan komunikasi dan pengadaan berbagai fasilitas pendukung lainnya.
Nabi selalu berpesan kepada para gubernur yang dia angkat untuk memimpin suatu wilayah agar meringankan beban masyarakat salah satunya dengan pembangungan infrastruktur. Pemerintah Islam harus mengalokasikan dana pada kegiatankegiatan seperti pengadaan sarasan kesehatan, panti, dan menciptakan lapangan kerja. Dalam peningkatan taraf hidup sehat, pemerintah wajib menyediakan tempat seperti rumah sakit, pusat kesehatan masyarakat, penyediaan obat-obatan dan sosialisai hidup sehat kepada masyarakat secara langsung. Selain itu pemerintah juga bisa mencanangkan sebuah program pelayanan kesehatan gratis seperti kartu sehat, atau dengan menerapkan sistem pembiayaan subsidi silang. Hal ini bertujuan agar masyarakat bisa saling membantu satu sama lain baik secara individu maupun kolektif.

\section{Pendidikan}

Semangat pentingnya pendidikan didasari dari pernyataan Nabi SAW yang mengatakan bahwa menuntut ilmu merupakan kewajiban setiap muslim. Tujuan pendidikan dalam Islam ialah melahirkan para muslim yang dapat menyesuaikan diri dengan cita-cita yang terkandung dalam ajaran al Qur'an dan Sunnah Nabi SAW, mengajarkan keterampilan yang memiliki relevansi 
dengan kebutuhan masyarakat serta pembangungan infrastruktur dan fasilitas menstimulasi insentif riset dan penemuanpenemuan teknik baru pengolahan sumber sosial, dan bidang pendidikan. Sehingga dapat ditarik sebuah kesimpulan sederhana bahwa daya yang disediakan oleh Allah SWT dengan baik. Oleh karena itu pemerintah sangat dituntut untuk bisa memberikan perhatian lebih terhadap pengembangan dan pembangunan sektor pendidikan. Karena hal ini merupakan syarat mutlak bagi peningkatan kualitas sumber daya manusia.

sumber pendapatan negara harus mempertimbangkan nili-nilai fundamental dalam ajaran Islam baik yang bersumber dari Al-Qur'an, Hadis, maupun ijtihad ulama.

\section{Pustaka Acuan}

A.A. Ishlahi. Konsepsi Ekonomi Ibn Taimiyah. (Surabaya: Bina Ilmu Offset, 1997). h. 252-253.

\section{Penutup}

Kebijakan politik keuangan negara menentukan laju perkembangan negara menuju perbaikan secara dinamis dan bukan justru bertahan pada keadaan statis. Negara harus mampu memforrmulasikan cara-cara terbaik guna menentukan kebijakan sumber pemasukan keuangan negara. Selain itu juga diperlukan perhatian khusus dalam melakukan perencanaan terbaik guna memanfaatkan hasil pendapatan dari sumber-sumber yang diperoleh. Seperti yang telah diterangkan secara jelas di dalam nash baik secara naqli maupun aqli, ditemukan bahwa sumber keungan negara dalam tataran ajaran Islam bisa dibagi menjadi beberapa macam seperti, zakat, ghanimah, Fai', Jizyah, dan Kharaj/pajak. Selain itu juga hasil pendapatan dari sumber-sumber di atas bisa dimanfaatkan untuk kepentingan publik seperti pemberantasan kemiskinan, pertahanan dan keamanan negara, pembangunan hukum,

Bintoro Tjokroaminodjojo. Pengantar Administrasi Pembangunan. (Jakarta: LP3ES, 1985).

Imam Al Mawardi. Al-Ahkam AsSulthaniyyah: Hukum-hukum Penyelenggaraan Negara dalam. Syariat Islam. (Bekasi: Darul Falah. 2017).

Inu Kencana Syafiie. Al Qur'an dan Ilmu Politik. (Jakarta: Rineka Cipta. 1996.)

M Nuruddin.’Transformasi Hadis-Hadis Zakat dalam Mewujudkan Ketangguhan Ekonomi pada Era Modern. Jurnal Zakat dan Wakaf Vol. 1, No. 2, Desember 2014.

Muhammad Ashraf. Economic System Under Umar The Great, terjemahan Irfan Mahmud Ra'na, Sistem Ekonomi Pemerintahan Umar Ubn Al-Khathab. (Jakarta: Pustaka Firdaus, 1992).

Muhammad Iqbal. Fiqh Siyasah: Kontekstualisasi Doktrin Politik Islam 
AL-IMARAH: Jurnal Pemerintahan dan Politik Islam

Vol. 4, No. 1, 2019

Edisi Pertama. (Jakarta: Prenadamedia

Group. 2014. )

Prajudi Atmosudirdjo. Hukum Administrasi

Negara. (Jakarta: Ghalia Indonesia, 1983).

Sayyid Quthb. Al-Adalah al-ijtima'iyah fi alislam (Kairo: Dar al-Kitab al-'Araby, 1980). h. 32 sebagaimana yang terdapat dalam Muhammad Iqbal. Fiqh Siyasah: Kontekstualisasi Doktrin Politik Islam Edisi Pertama. (Jakarta: Prenadamedia Group. 2014. )

Soehino. Ilmu Negara. Edisi Kedua, Cetakan Pertama. (Yogyakarta: Liberty. 1986. )

Umer Chapra. Negara Sejahtera Islami dan Perannya di Bidang Ekonomi. Dalam Ainur R. Sophiaan (Ed), Etika Ekonomi Politik Elemen-Elemen Strategis Pembangunan Masyarakat Islam. (Surabaya: Risalah Gusti,1997). 